\title{
M-Banking: The Transaction Revolution in Bangladesh
}

\author{
Md. Tareq Hasan \\ Department of Business Administration, Sheikh Fazilatunnesa Mujib University, Jamalpur, Bangladesh \\ Email address: \\ tareq_sfmu@outlook.com, tareq.sfmu@gmail.com

\section{To cite this article:} \\ Md. Tareq Hasan. M-Banking: The Transaction Revolution in Bangladesh. Science Research. Vol. 8, No. 4, 2020, pp. 98-107. \\ doi: $10.11648 /$ j.sr.20200804.12
}

Received: April 19, 2020; Accepted: May 22, 2020; Published: August 27, 2020

\begin{abstract}
Bangladesh is a developing country where mobile network operators had been started from 1993 through AMPS (Advanced Mobile Phone Service) and later on CDMA (Code-Division Multiple Access) technology was introduced and mobile banking facilities were started clearly under a guideline of the central bank of Bangladesh on 'Mobile Financial Services for Banks' in September 2011. Though m-banking is a newer service in the country meanwhile it has got very popularity within a short time due to inadequate traditional banking facilities. In this study, mobile banking of Bangladesh has been emphasized on some transactional usages and with a new concept. There are many villages in Bangladesh where no financial institution exists physically for financial transactions yet. Through this study, the researcher also found that many villages are very far away from the bank area. But people who have no bank accounts are now habituated with mobile banking facilities and happy with the services. Since some financial institutions are allowing their subscribers (mobile banking account holders) to use ATM facilities for cash withdrawal, so the m-banking is being popular in the village, semi-urban, urban, and city areas. The subscribers are being accustomed to mobile banking services and the users are also increasing tremendously with time.
\end{abstract}

Keywords: Mobile Banking or M-Banking, Transaction, Service, Payment, User

\section{Introduction}

Mobile commerce services were first delivered in 1997 and during that time the first two mobile phone companies enabled Coca-Cola vending machines were installed in the Helsinki area in Finland. The machines accepted payment via text SMS for getting the product. Then, this work evolved to several new mobile applications using SMS such as the first mobile phone-based banking service was launched in 1997 by Merita Bank of Finland. Mobile commerce-related services spread rapidly in early 2000. For example, Norway launched mobile parking payments, Austria offered train ticketing via mobile devices, and Japan also offered airline tickets purchasing facilities by mobile phone for its people.

M-banking stands for Mobile Banking. Mobile banking is a part of m-commerce or wireless e-commerce. Any personal or business transaction involving the transfer of ownership or rights to use money (hard or soft) by any bank or financial institution which is facilitated by using mobile devices with wireless access technology is called mobile banking. Without any physical existence of branch it may transact money. It may also call mobile commerce. That is, m-commerce involves the delivery of electronic commerce facilities through cell phones or the same type of other mobile devices by using Apps or USSD (Unstructured Supplementary Service Data) code.

According to the guideline of Bangladesh Bank (Central Bank of Bangladesh) may allow the following Mobile Financial Services (in broad categories):

1. Disbursement of inward foreign remittances.

2. Cash in /out using mobile accounts through agents/Bank branches/ ATMs/Mobile Operator's outlets.

3. Person to Business Payments - e.g. a. utility bill payments, b. merchant payments

4. Business to Person Payments e.g. salary disbursement, dividend and refund warrant payments, vendor payments, etc.

5. Government to Person Payments e.g. elderly allowances. Freedom-fighter allowances, subsidies, etc.

6. Person to Government Payments e.g. tax, levy payments.

7. Person to Person Payments (One registered mobile Account to another registered mobile account). 
8. Other payments like microfinance, overdrawn facility, insurance premium, DPS, etc [3].

There are more than $65 \%$ of the people live in the rural and semi-urban areas where the formal financial institutions and their services are almost insufficient. Approximately $17 \%$ of the population is connected to the formal banking system in Bangladesh and near about 30 million active account holders exist. A large number of people are dependent on other mediums for transactions. For this reason still, now the people send or receive their money by using courier services and even through inter-district bus services. These trends are being changed and people are being habituated with mobile banking services. These changing trends are increasing day by day and according to the last update (February, 2020) of the central bank, more than 80.92 million people are registered clients along with 33.30 million active users of mobile banking services which growing upward.

There is no charge to open mobile banking accounts and only the user's photo and national identity are enough to cover paper requirements for an account. Consumers can operate their accounts through cell phones using USSD code or apps of the mobile banking service operator. There are some features for users that he or she can use such as send money, cash in and out, pay bills, shopping, mobile recharge and many more. A personal account can cash-in maximum five times per day with an amount of Tk. 30,000 that was Tk. 15,000 previously and two transactions were permitted a day along with monthly total cash-in limit has been raised to Tk. 200,000 from Tk. 100,000. Cash-out limit has also been extended to maximum Tk. 25,000 and a personal account holder can cash-out a maximum of five times, as well. Earlier, it was Tk10,000 and two times per day. An MFS subscriber can cash-out Tk. 150,000 per month now, which was Tk50,000 before [7].

The maximum service charge on a transaction is seventeen taka and fifty paisa (Tk. 17.50) per thousand through USSD code and fifteen taka (Tk. 15) per thousand by using apps. Some service provider of mobile banking allows to cash out through their ATMs and the maximum charge for that is fifteen taka (Tk. 15) per thousand and mobile banking feature also has been added therein ATM machines. To send money to others may be charged a maximum five taka (Tk. 5) after certain transactions [5]. The listed features are near about same for all of USSD code and apps. The common features of mobile banking are cash in and out, send money, payment, buy airtime, interest on service and bank account management, and international remittance.

Table 1 represents comparative summarized data of mobile financial services of January and February 2020 where the total transacted amount was 42.1 trillion and 41.3 trillion taka respectively. Where currently 15 service providers are providing mobile banking facilities and its users are more than active account holders in the formal banking system in Bangladesh. But NCC (National Credit and Commerce) Bank Limited has closed its mobile financial services since February 2020. Mentioned active accounts in this table considered those accounts transact for the last three (3) months [4].

Table 1. Mobile Financial Services (MFS) comparative summary statement of January, and February 2020.

\begin{tabular}{|c|c|c|c|c|}
\hline $\begin{array}{l}\text { Serial } \\
\text { no. }\end{array}$ & Description & $\begin{array}{l}\text { Amount in January, } \\
2020\end{array}$ & $\begin{array}{l}\text { Amount in February, } \\
2020\end{array}$ & $\begin{array}{l}\text { \% Change (January, } 2020 \text { to } \\
\text { February, 2020) }\end{array}$ \\
\hline 1 & No. of Banks currently providing the Services & 16.00 & 15.00 & $\begin{array}{l}\text { NCC Bank Ltd. has closed all their } \\
\text { MFS accounts. }\end{array}$ \\
\hline 2 & No. of agents & $981,537.00$ & $985,914.00$ & $0.45 \%$ \\
\hline 3 & No. of registered clients in Lac & 809.16 & 818.57 & $1.16 \%$ \\
\hline 4 & No. of active accounts in Lac* & 332.94 & 270.87 & $-18.64 \%$ \\
\hline 5 & No. of total transaction & $230,090,192.00$ & $226,109,405.00$ & $-1.73 \%$ \\
\hline 7 & No. of daily average transaction & $7,422,264.26$ & $7,796,876.03$ & $5.05 \%$ \\
\hline 8 & Average daily transaction (in crore BDT) & $1,358.17$ & $1,425.34$ & $4.95 \%$ \\
\hline 9 & Product wise information & Amount (in crore BDT) & Amount (in crore BDT) & \\
\hline a. & Inward Remittance & 29.68 & 29.99 & $1.04 \%$ \\
\hline b. & Cash In transaction & $14,947.64$ & $14,634.91$ & $-2.09 \%$ \\
\hline c. & Cash Out Transaction & $13,929.62$ & $13,706.13$ & $-1.6 \%$ \\
\hline d. & $\mathrm{P} 2 \mathrm{P}$ transaction & $10,077.95$ & $9,796.98$ & $-2.79 \%$ \\
\hline f. & Utility Bill Payment (P2B) & 472.02 & 441.12 & $-6.55 \%$ \\
\hline g. & Merchant Payment & 627.77 & 581.89 & $-7.31 \%$ \\
\hline h. & Government Payment & 152.34 & 275.50 & $80.84 \%$ \\
\hline i. & Others & 782.58 & 780.53 & $-0.26 \%$ \\
\hline
\end{tabular}

Source: Bangladesh Bank.

[1 lac $=0.10$ million and 1 crore $=10$ million $]$.

Actual No of days in months have been used for average calculations.

\section{Literature Review}

Many articles and reports have been published on different topics in mobile banking or finance over the world and few of those are illustrated in this part of the research shortly.

Finance Minister AMA Muhit stated that mobile banking is increasing Tk. 994 crore in daily transactions on an average. The total number of mobile banking customers stands at 64 million. Bangladesh receives commitments amounting to 
$\$ 14.61$ billion in foreign assistance from different countries and donor agencies in 2017-2018 (Star Business Report, 2018) [14]. But now in 2020 (February) the number of registered clients are 80.9 million and active users are 33.3 million.

According to USAID report Bangladesh has a rapidly growing mobile financial service industry, accounting for more than 8 percent of the total registered mobile money accounts globally. The country launched such products in 2011 and in five years, the market hit the highest position in the world so far. (Islam, 2016) [8].

Dutch-Bangla Bank pioneered Mobile Banking in Bangladesh. It was the first bank to offer banking facilities through a wide range of mobile phones. Rocket is a Banking process without a bank branch that provides financial services to unbanked communities efficiently and at an affordable cost. To provide banking and financial services, such as cash-in, cash-out, merchant payment, utility payment, salary disbursement, foreign remittance, government allowance disbursement, ATM money withdrawal through mobile technology devices (Dutch-Bangla Bank Limited, 2019) [6]. At first it was introduced as 'Dutch Bangla Mobile Banking' in the market and did not get expected results. But after changing its name in short as 'Rocket' the popularity has been increased.

Mahzabin revealed that in Bangladesh, mobile banking beneficial to rural people like farmers, village businessmen. By signing up in mobile banking, the difficulties of the transaction of money have been dispelled. It is difficult to go to the bank for rural people as the nearest one is some miles away from their house. But mobile banking is close to their home. They can receive and send money quickly and easily with a mobile phone or by going to the nearest agent in the local market. The villagers who left their school at an early age and unable to read and write, they can use a mobile phone for transferring money without the hassles to fill up a form in writing. It makes their life easier.

Andrew, 2009, stated in his report that mobile banking users can now conveniently carry out banking transactions, but this convenience cannot be achieved if the user does not have access to the internet, hence, in other words, the user cannot carry out a banking transaction while waiting for a bus or perhaps while having lunch in a restaurant. But the user of Bangladesh may use their m-banking with the internet (using Apps) and without internet (using USSD coding). A wide spectrum of mobile/branchless banking models is evolving. However, no matter what business model, if mobile banking being used to attract low-income populations in often rural locations, the business model will depend on banking agents, i.e. retail or postal outlets that process financial transactions on behalf of telecoms or banks, he added [2].

Pathak\& Mishra, 2019 mentioned in their research that mobile banking provides various facilities like performing banking transactions, access, and administers the accounts and information. The launch of Mobile banking in India has increased the growth of transactions through the phone.
Mobile banking provides the facility of round the clock and eases to use which has attracted a large number of people. They also mentioned that the majority of people prefer to use the traditional form of banking rather than going for mobile banking [13].

Ondiege, 2010 illustrated in his report that the majority of the population of Africa has no access to banking services, with only $20 \%$ of African families having bank accounts. For instance, in 2007 , only about $30 \%$ of household in Kenya had bank accounts; and in Benin, with a population of 7 million had only 35 bank branches in 2006. The limited access to financial services in Africa stems particularly from deficient infrastructure, physical-geographical isolation or inaccessibility, financial illiteracy, all of which culminate into exceedingly high cost of providing banking services. Ethiopia, Uganda, and Tanzania for instance, each has less than one bank branch per every 100,000 people. This ratio however shows a high disparity across the continent, with Namibia having more than four, Zimbabwe more than three and Botswana nearly four bank branches per 100,000 people. But now most of the African people who have cell phones are connected with mobile banking facilities [12].

Karnouskos \& Vilmos, 2004 had focused on their conference paper on mobile payment of European people. As one can easily anticipate, a Europe-wide mobile payment service had to successfully tackle the requirements arising from the main actors in such a scenario i.e. the users, the merchants, the mobile operators and the financial service providers. For a service to be accepted, a critical mass must be achieved in a context compliant with the European Commission's vision of a mobile Europe, where its citizens freely move among the EU countries, and seamlessly enjoy services coming from the communication, banking, government, and health domains, they also added. It was a challenge initially but now it has been accepted for hasslefree transaction or payment [9].

\section{Objectives of the Study}

The objectives of the study are;

1. To show the transaction facilities in different fields in the country.

2. To share some recommendations of the respondents and researcher.

3. To illustrate a new concept for transactions among one another mobile banking service provider.

\section{The Methodology of the Study}

To achieve the objectives of the study both primary and secondary data have been used in this research. The primary data has been collected from some cities, semi-urban and rural areas of the country through a structured questionnaire. There were eight districts with capital covered for conducting field survey and total respondents were a hundred and five (105) for this paper. The visited districts are Dhaka, Jamalpur, Sherpur, Mymensing, Tangail, Kurigram, 
Sirajganj, and Bogura in Bangladesh and students, different kinds of service holders, farmers and so on have been selected as population of the sample. The primary data were inputted into an MS Excel file to make tables and charts. The secondary data has been taken from the internet, articles, newspapers, conference papers, reports, and so on as well as the current scenario of mobile financial service providers.

Limitations of the study: The overall country was not considered for field survey and only a hundred and five (105) respondents were included for this study. The self-rated questionnaire might be biased on the responses of the respondents. The cash inflow, and outflow services of mobile banking have been considered for this paper and a few agents of mobile financial services have been conducted for primary data collection. The consumer attitude may change with time.

A few studies that included in the literature review part and this research will help the financial service operator and its manager as well as new research scopes will be opened in future. American English has been used to analyze the paper through the descriptive method.

\section{Findings of the Study}

This part of the study reports the overall demographic features of the survey. The mobile banking facilities have made a significant bond over the country for the transaction which is a revolution in Bangladesh. Most of all survey participants are officially registered users and a few are nonregistered of mobile banking. Yet, most of all participants are using mobile banking for their self demand. The tables and figures are described shortly below based on field survey respectively.

Table 2 covers the age distribution of the respondents and their percentage. In this table the least age of the respondents is fifteen (15) those who are under aged (below 18) and the maximum age of the respondent is 65 years old. Thirty-eight (38) respondents are maximum frequency among all and their age range of fifteen to twenty-four (15-24) years old which indicates that new generation people are very friendly with mobile banking.

Table 2. Age Range of Respondents.

\begin{tabular}{lll}
\hline Year & Respondents & Percentage \\
\hline $15-24$ & 38 & $36 \%$ \\
$25-34$ & 34 & $32 \%$ \\
$25-44$ & 16 & $15 \%$ \\
$45-54$ & 12 & $12 \%$ \\
$55-64$ & 5 & $5 \%$ \\
Total & 105 & $100 \%$ \\
\hline
\end{tabular}

Source: Primary Data.

On the other hand, aged people are not habituated with these services and the table 2 contains only five (5) respondents among a hundred and five (105) those who are within the age range of fifty-five to sixty-four (55 to 64) years old.

The pie chart (figure 1) shows the percentage of the age range of total respondents and the lowest age of them is fifteen (15) and the highest is sixty-four (64) years. Thirty-six percent $(36 \%)$ of the respondents are within the age range of fifteen to twenty-four (15-24) years old; Thirty-two percent $(32 \%)$ are within the age range of twenty-five to thirty-four (25-34) years old;

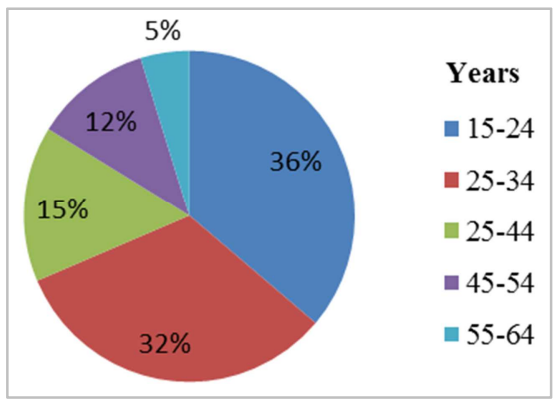

Figure 1. Age Range of Respondents.

Twelve percent $(12 \%)$ of the respondents are within the age range forty-five to fifty-four (45-54) and five percent $(5 \%)$ of them are within the age range fifty-five to sixty-four (55-64) years old.

Table 3 is showing various types of professionals. The highest frequency of the respondents (43) is students and others (9) are mixed groups of professionals. The table also contains business persons, service holders, and farmers.

Table 3. Occupation of Respondents.

\begin{tabular}{lll}
\hline Occupation & Respondents & Percentage \\
\hline Student & 43 & $41 \%$ \\
Business & 19 & $18 \%$ \\
Service & 26 & $25 \%$ \\
Farmers & 8 & $8 \%$ \\
Others & 9 & $8 \%$ \\
Total & 105 & $100 \%$ \\
\hline
\end{tabular}

Source: Primary Data.

Figure 2 represents the professional percentage of the respondents. Based on the survey, forty-one percentages $(41 \%)$ of the respondents are students, twenty-five percentages $(25 \%)$ are service holders, eighteen percentages $(18 \%)$ are business persons, farmers are eight percent $(8 \%)$ and others are total eight percent (8\%) among all.

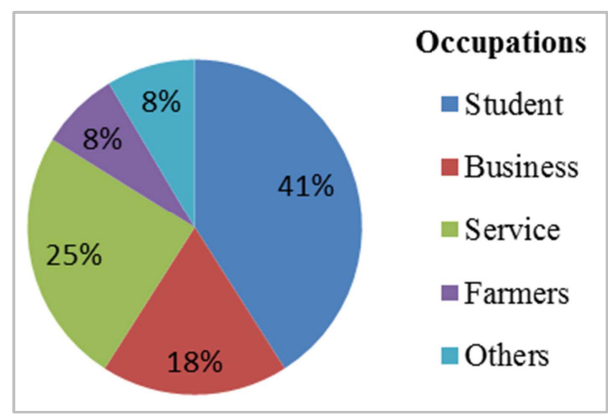

Figure 2. Occupation of respondents.

As per the information of the central bank, there are a total of 15 mobile banking service providers are providing $\mathrm{m}$ banking facilities over the country and in February 2020, a 
bank has closed its mobile banking operation. As per primary data, bKash and Rocket is competitor of one another and others are growing up operators only. But, Nagod is growing faster in the market.

Table 4. Usage of M-Banking.

\begin{tabular}{lll}
\hline Usage M-Banking & Respondent & Percentage \\
\hline bKash & 51 & $48 \%$ \\
Rocket & 22 & $21 \%$ \\
bKash and Rocket & 18 & $17 \%$ \\
bKash, Rocket and Others & 6 & $6 \%$ \\
User Without M-Banking Account & 8 & $8 \%$ \\
Total & 105 & $100 \%$ \\
\hline
\end{tabular}

Source: Primary Data.

Table 4 covers usage of mobile banking where fifty-one (51) respondents use the bKash only and twenty-two (22) persons use Rocket. Eighteen (18) persons use both bKash and Rocket and Six (6) persons use bKash, Rocket and Others (U-Cash, T-Cash, Nagod etc.). Here, only 8 persons exist those who use mobile banking facilities but don't have their own accounts (non-registered user).

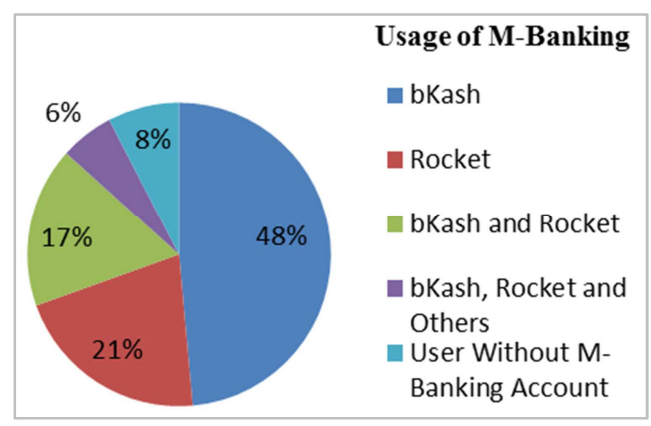

Figure 3. Usage of M-Banking.

In terms of usage of mobile banking, the pie chart (figure 3) shows usages percentage of mobile banking. Forty-eight percent (48\%) respondents use bKash; Twenty-one percent (21\%) uses Rocket; bKash and Rocket both account holders are $17 \%$ and some persons $(6 \%)$ maintain more than two mobile banking service account. Another eight percent ( $8 \%$ ) take mobile banking facilities but they don't have own account which may call nonregistered user.

Table 5 contains the information on bank accounts of respondents. Except students, most of the other professionals have got their bank account in different banks of Bangladesh. Yet they are transacting through mobile banking services to avoid time-consuming along with for some limitations of physical banks.

Table 5. Bank Account Holders.

\begin{tabular}{lll}
\hline Details & Respondents & Percentage \\
\hline Account Holders & 58 & $55 \%$ \\
No Account & 47 & $45 \%$ \\
Total & 105 & $100 \%$ \\
\hline
\end{tabular}

Source: Primary Data.
In the table there are two types of respondent one is bank account holders which is fifty-eight (58) persons and the other is forty-seven (47) individuals who are without a bank account.

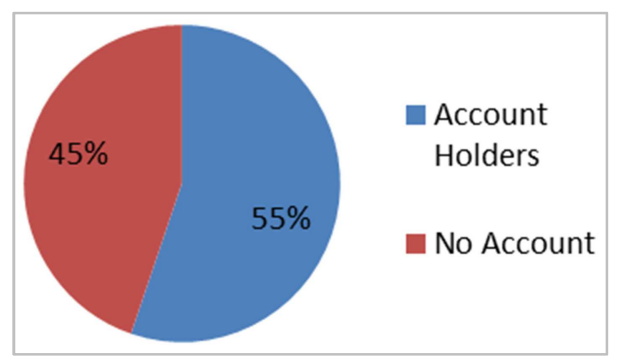

Figure 4. Bank account holders.

Figure 4 shows the percentage of physical bank account information of the respondents. Fifty-five percent $(55 \%)$ of the total respondents have their bank account in different physical banks and the other forty-five percent (45\%) do not have any bank account.

Table 6. Transaction Amount per Month.

\begin{tabular}{lll}
\hline Amount in (Tk.) & Respondent & Percentage \\
\hline $500-1000$ & 9 & $9 \%$ \\
$1000-2000$ & 13 & $12 \%$ \\
$2000-5000$ & 26 & $25 \%$ \\
$5000-10000$ & 33 & $31 \%$ \\
$10000-20000$ & 18 & $17 \%$ \\
Above 20000 & 6 & $6 \%$ \\
Total & 105 & $100 \%$ \\
\hline
\end{tabular}

Source: Primary Data.

Table 6 covers the transaction per month of the respondents. The table contains a minimum transaction amount is five hundred (Tk. 500) and the maximum amount is more than twenty thousand (Tk. 20,000) only. Most of the respondents that are, thirty-three (33) are transacted five to ten thousand (Tk. 5,000-10,000) per month for different purposes.

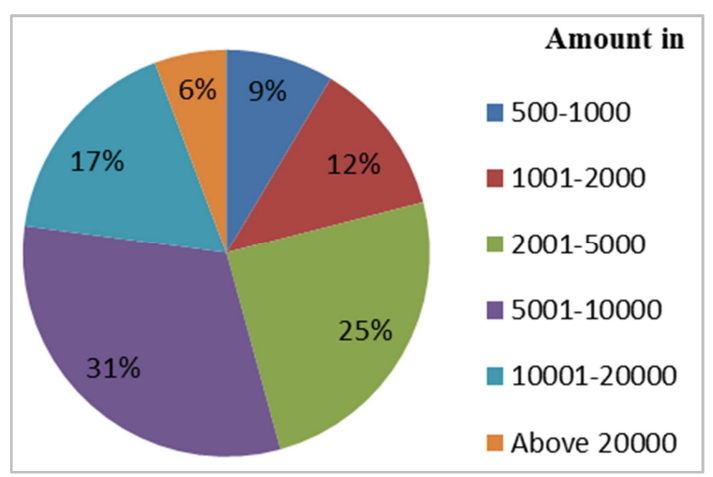

Figure 5. Transaction amount per month.

Figure 5 shows the percentages of the transaction amount of respondents per month. Nine percent (9\%) respondents transact only from five hundred (Tk. 500) to one thousand (Tk. 1,000) taka per month; twelve percent 
$(12 \%)$ transacts one thousand and one (Tk. 1,001) to two thousand (Tk. 2,000) taka per month; twenty-five percent $(25 \%)$ transacts two thousand and one (Tk. 2,001) to five thousand (Tk. 5000) taka per month; most of the respondents that are, thirty-one percent (31\%) transact five thousand and one (Tk. 5,001) to ten thousand (Tk. $10,000)$ taka per month; seventeen percent $(17 \%)$ transacts ten thousand and one (Tk. 10,001) to twenty thousand (Tk. $20,000)$ taka, and six percent $(6 \%)$ transact more than twenty thousand (Tk. 20,000) taka per month.

Table 7. Transaction Trends per Month.

\begin{tabular}{lll}
\hline Usage Trends & Respondents & Percentage \\
\hline $01-02$ & 22 & $21 \%$ \\
$03-05$ & 32 & $30 \%$ \\
$06-08$ & 24 & $23 \%$ \\
$09-12$ & 14 & $13 \%$ \\
$13-15$ & 06 & $6 \%$ \\
$16-20$ & 05 & $5 \%$ \\
Above 20 & 02 & $2 \%$ \\
Total & 105 & $100 \%$ \\
\hline
\end{tabular}

Source: Primary Data.

Table 7 covers the transaction trends of respondents per month. The least trends of transactions are 01 (one) to 02 (two) times per month and maximum respondents (32) transact 03 (three) to 05 (five) times per month. Twenty-four (24) respondents transact within 06 (six) to 08 (eight) times, fourteen (14) respondents do 09 (nine) to 12 (twelve) times transaction per month. The table shows only two (02) respondents use mobile banking transaction facilities for more than 20 (twenty) times per month.

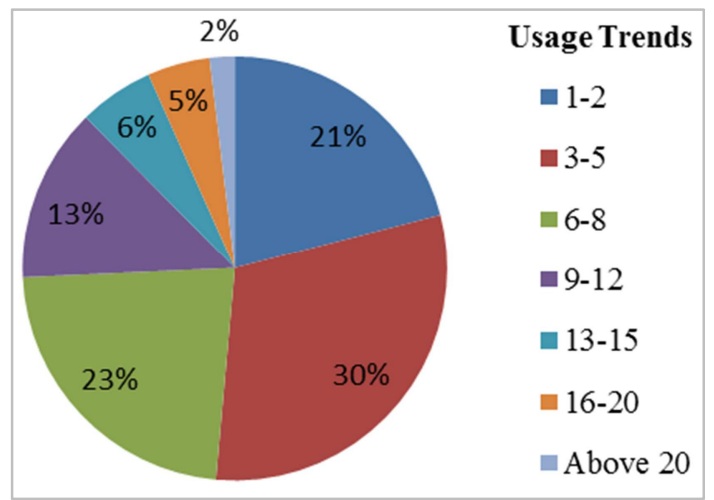

Figure 6. Transaction trends per month.

Figure 6 illustrates twenty-one percent (21\%) of respondents transact one to two (1-2) time and only two percent $(2 \%)$ of respondents do more than 20 (twenty) transactions per month. In general, thirty percent $(30 \%)$ and twenty-three percent $(23 \%)$ of total respondents transact three to five (3-5) and six to eight (6-8) time per month respectively. Significantly, thirteen percent (13\%) respondents do nine to twelve (9-12) transactions per month.

Table 8 covers the purposes of frequent usage of mobile banking. The most common use of mobile banking is balance transfer between the subscribers or users and near about all the respondents transfer their balance for different purposes. Mobile recharge is another significant usage for the users but less than balance transfers.

Table 8. Purposes of Using M-Banking.

\begin{tabular}{llllll}
\hline \multirow{2}{*}{ Purpose of Usage } & \multicolumn{5}{l}{$\mathbf{5}$ For Most and } \\
\cline { 2 - 6 } & $\mathbf{5}$ & $\mathbf{4}$ & $\mathbf{3}$ & $\mathbf{2}$ & $\mathbf{1}$ \\
\hline Balance Transfer & 66 & 23 & 12 & 3 & 1 \\
Mobile Recharge & 37 & 26 & 13 & 3 & 0 \\
Shopping & 2 & 6 & 9 & 12 & 14 \\
Utility Bill Payment & 0 & 3 & 6 & 13 & 15 \\
Others & 0 & 0 & 1 & 1 & 5 \\
\hline
\end{tabular}

Source: Primary Data.

Payment through m-banking is also a part of modern etransactions that going to be a popular method of payment for lucrative offers by mobile banking outlets (especially shops or supermarkets). Utility bill payment such as electricity, gas, telephone, etc. is also growing up usage to users. Other payments like application fees, tuition fees are paid nowadays.

Figure 7 shows the purposes of using mobile banking based on table 8 . The highest point of usage of m-banking is a balance transfer and the lowest point of usage is other purposes of payments. The points of mobile recharge are higher than shopping and utility bill payments. Cash back or discount policies on purchasing through m-payment (payment by mobile banking) encourage the subscribers to use m-banking more. So, shopping by m-banking is growing more gradually with time and the bars of shopping are higher than utility bill payments and others. But comparing with other payments, utility bill payment is higher in the figure.

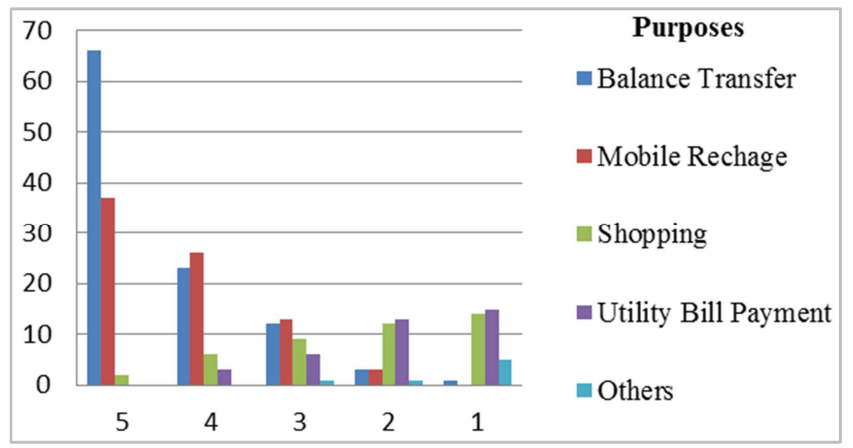

Figure 7. Purposes of using mobile banking.

Table 9 covers the purposes of payment. The payments through mobile banking are maybe for personal or business or both. Most of the respondents (total 85 persons) pay by mbanking for personal issues and the only four (04) respondents transact merely for business payment. A total of sixteen (16) respondents pay for both personal and business purposes by $\mathrm{m}$-banking indifferent areas. 
Table 9. Purposes of Payment.

\begin{tabular}{lll}
\hline Purpose of Payment & Respondents & Percentage \\
\hline Personal Payment & 85 & $81 \%$ \\
Business Payment & 4 & $4 \%$ \\
Both (Personal \& Business) Payments & 16 & $15 \%$ \\
Total & 105 & $100 \%$ \\
\hline
\end{tabular}

Source: Primary Data.

Figure 8 shows the purposes of payment using mobile banking in a pie where eighty-one percent $(81 \%)$ of total respondents use m-banking for personal payment only. Remaining fifteen percent $(15 \%)$ pay for both personal and business purposes. Only four percent (4\%) respondents use mobile banking facilities for business purposes.

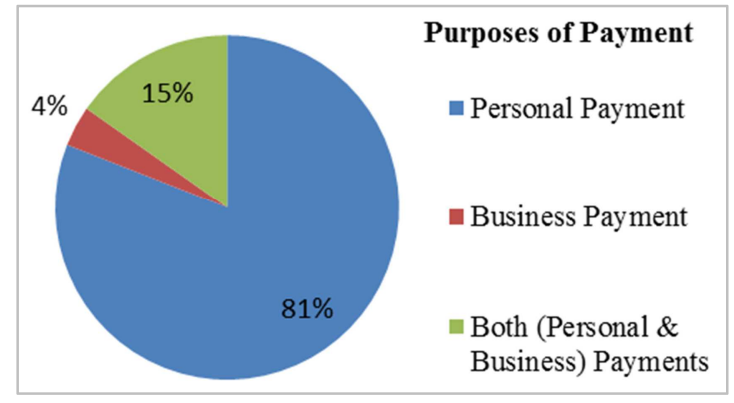

Figure 8. Purposes of payment.

Table 10 consists of a balance range that keeps by mobile banking users in accounts. According to survey response, most of all students (about 31 respondents) keep the lowest amount up to five hundred taka (Tk. 500) and some respondents have no account but transact from agents or friends and family users. But female students (about 10) keep more than five hundred (Tk. 501 above) since they can recharge their mobile phone and online shopping. Many people keep from more than one thousand to five thousand taka (Tk. 1001-5000) as a minimum balance of m-banking to transact for different purposes.

Table 10. Range of Balance Keeping.

\begin{tabular}{lll}
\hline Range of Amount (Tk.) & Respondents & Percentage \\
\hline $0-100$ & 21 & $20 \%$ \\
$101-500$ & 10 & $9 \%$ \\
$501-1000$ & 19 & $18 \%$ \\
$1001-5000$ & 24 & $23 \%$ \\
$5001-10000$ & 17 & $16 \%$ \\
Above 10000 & 6 & $6 \%$ \\
Without Account & 8 & $8 \%$ \\
Total & 105 & $100 \%$ \\
\hline
\end{tabular}

Source: Primary Data.

Seventeen (17) respondents keep up to ten thousand (Tk. $5,001-10,000)$ as an operational balance for multipurpose and most of them are businessmen and few of them are service holders who get their salary through mobile banking. The field survey also found some business persons maintain their balance above ten thousand taka (above Tk. 10,000) for their business transaction and they save time by avoiding physical banking.

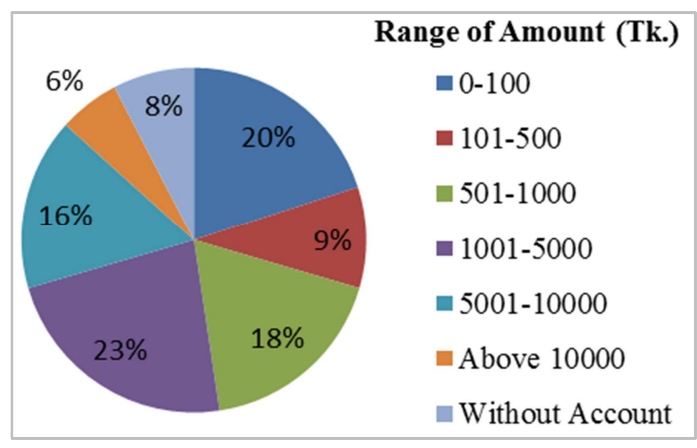

Figure 9. Range of balance keeping.

Figure 9 reveals the range of balance keeping by the users where twenty-three percent $(23 \%)$ that is the highest respondents keep a thousand one to five thousand taka (Tk. $1,001-5,000)$ and six percent $(6 \%)$ keeps above ten thousand (above Tk. 10,000) for their multipurpose operations. According to primary data, the first two range zero to a hundred taka (Tk. 0-100) and a hundred one to five hundred taka (Tk. 101-500) are mostly kept by the student respectively twenty percent $(20 \%)$ and nine percent $(9 \%)$. Eighteen percent (18\%) respondents are given information that they keep their balance from five hundred one to one thousand (Tk. 501-1000) taka since they recharge their mobile account using it. A significant percent, that is sixteen percent $(16 \%)$ respondents receive and pay by using mobile banking and the amount of balance is within five thousand one to ten thousand (Tk. 5,000-10,000). There is eight percent $(8 \%)$ respondents also exist those who do the transaction without own account.

Table 11 covers the common problems that are frequently faced during transactions through mobile banking. More or less, the respondents face the network problem in many areas of the country. Especially, during Eid or any national ceremony when transactions are made more. The most common other two problems are limitations in the transaction and insufficient balance of the agents. The field survey reveals to us that the users of the rural areas face problems to withdraw much money due to insufficient balance of the agents along with the availability of agents which is less in urban or city areas. Other problems like money not sending, balance adjusting, etc. are very few during the transaction.

Table 11. Common Problems during Transaction.

\begin{tabular}{llllll}
\hline \multirow{2}{*}{ Problem Details } & \multicolumn{6}{l}{ 5 For Most and 1 For Least } \\
& Frequently & & & \\
\cline { 2 - 6 } & $\mathbf{5}$ & $\mathbf{4}$ & $\mathbf{3}$ & $\mathbf{2}$ & $\mathbf{1}$ \\
\hline Network Problem & 29 & 11 & 12 & 13 & 16 \\
Limitation in Transactions & 12 & 19 & 16 & 10 & 14 \\
Insufficient Balance of Agent(s) & 6 & 10 & 13 & 12 & 18 \\
Availability of Agent & 13 & 6 & 8 & 9 & 12 \\
Others & 0 & 0 & 0 & 1 & 2 \\
\hline
\end{tabular}

Source: Primary Data.

Figure 10 describes the common problems of mobile banking during balance transfer. The highest point is on network problem and the lowest point is on others such as 
money not sending, balance adjusting, etc. The bar shows a limitation in transactions is a more common problem than insufficient balance and agent availability. Insufficient balance of agents is also a common problem and villagers face this problem more. But comparing with other problems, the availability of an agent is higher in the figure.

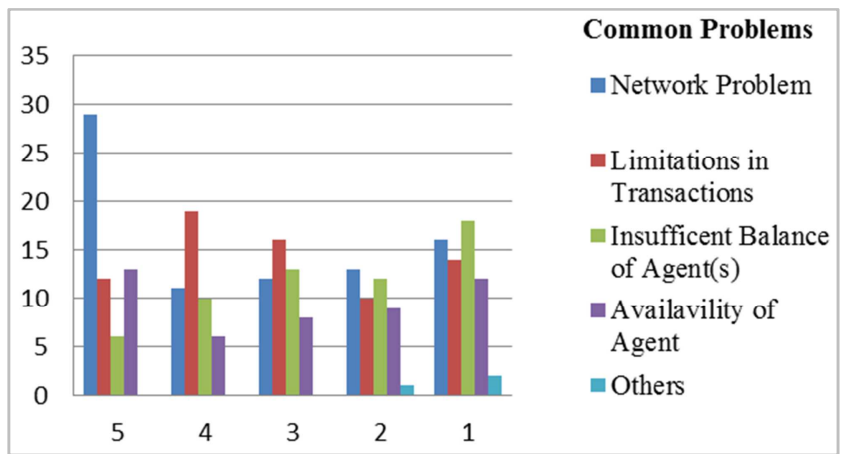

Figure 10. Common problems during the transaction.

Table 12 gives information regarding satisfaction and dissatisfaction on transaction charges for cash out from the agents. When a user goes for withdrawal cash from an agent then maximum taka eighteen and fifty paisa (Tk.18.50) is charged per thousand and taka twelve and fifty paisa (Tk. 12.50 ) is charged to withdraw of per thousand from ATM. Based on the survey most of the respondents do not satisfied. The rate of satisfaction is forty-one (41) and dissatisfied respondents are sixty-four (64) among overall participants.

Table 12. Charges on Transaction.

\begin{tabular}{lll}
\hline Details & Respondents & Percentage \\
\hline Satisfied & 41 & $39 \%$ \\
Not Satisfied & 64 & $61 \%$ \\
Total & 105 & $100 \%$ \\
\hline
\end{tabular}

Source: Primary Data.

The pie chart in figure 11 illustrates the customers' react to transaction charges per thousand. Sixty-one percent $(61 \%)$ of overall respondents are not satisfied and the remaining thirty- nine percent $(39 \%)$ is satisfied with the transaction charge. Nowadays, mobile financial service providers are decreasing the charges on transactions to sustain their business.

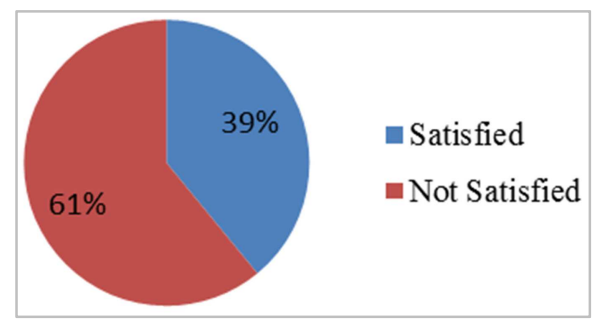

Figure 11. Charges on the transaction.

The user desires fewer service charges will be introduced; on the other hand the vendors would like to get more commission from the mobile banking service provider. With the help of the Central Bank, Association of Bankers, Bangladesh (ABBD) may consider the issue for the best result based on the economic basement of the country.

New Concept in Mobile Banking for Bangladesh

All the operators of mobile banking are working on intratransaction policies such as bKash to bKash or Rocket to Rocket or Nagod to Nagot. But the researcher thinks that it may transact like other commercial bank transactionsforexamplebKash, Rocket or any other service provider to any mobile banking service provider through a central server of Central Bank (Bangladesh Bank). That is, any mobile banking service operator will able to send or receive money from any other mobile banking service operators. The central bank will provide a code or serial number for each mobile banking service operator for their identity to transact among them (all mobile banking service provider). Initially 'send money' and 'cash out' may apply as a pilot implementation. The process may be: $<$ dial USSD common code $><$ Send Money or Cash out $><$ Self or Other Accounts $><$ Code of Other Service Provider $><$ Receiver Wallet No $><$ Amount $><$ Reference No $><$ Pin $>$. For more clarification a figure has been given below;

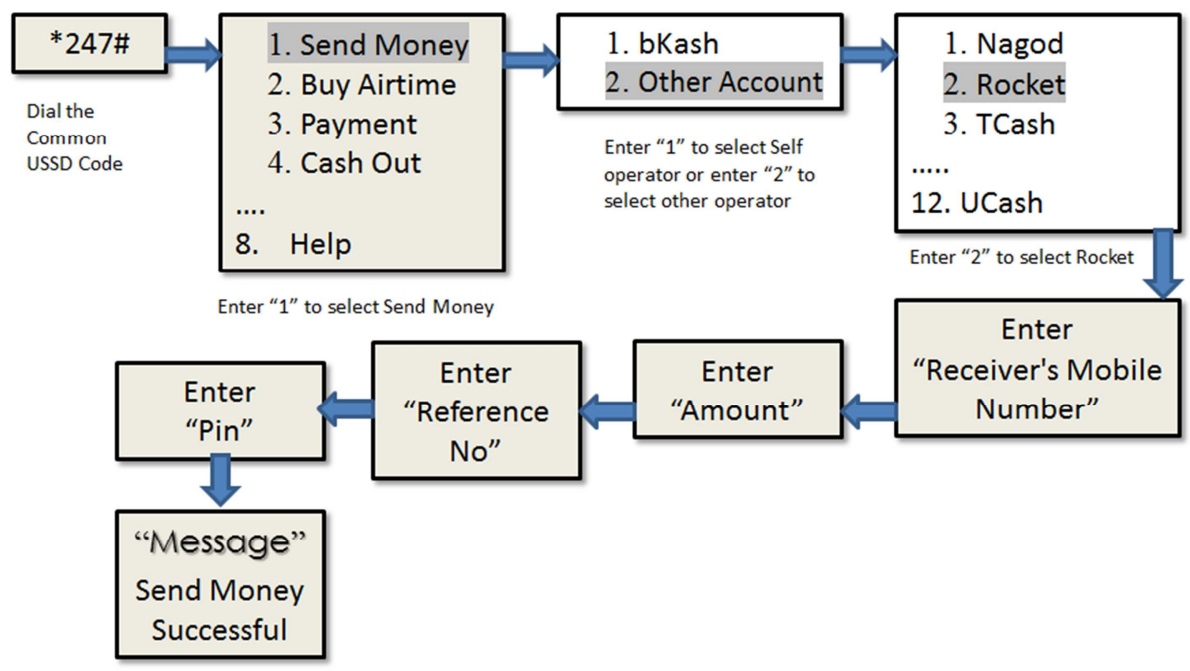

Figure 12. A new concept to send money (bKash to Rocket). 
Figure 12 shows the process of sending money from bKash to Rocket that is one mobile banking service provider is sending money to another mobile banking service provider by using additional two steps (Step 3 and 4) only. The service charge will be defined by the central bank rationally and the process will not face any problem since all the mobile number is unique.

Recommendations: Based on the survey and overall study, some recommendations of the respondents and researcher were mentioned below;

The mobile banking of Bangladesh should be synchronized as my new concept among all operators for the best m-banking transactions.

Payment acceptance should be wider so that people can transact 24/7 without writing any paper and a long queue.

The transaction limit should be increased for the personal user to ensure the purpose of $\mathrm{m}$-banking.

Adequate capital should be considered during agent selection and availability of agents over the country must be ensured so that the customers get prompt and better services.

All kinds of utility bills like eclectic, gas bills must be covered by mobile banking for minimizing customer hassle.

Network bandwidth maybe increased during Eid or other national ceremonies for uninterrupted transactions.

The transaction charge should be reduced considering the lower-income groups of the country.

Many potential customers or users exist in this market and the service operators should provide better service to get the overall market.

Mobile financial service operators may offer profits' percentage making some policies for its customers or subscriber like physical banks.

The mobile financial service opers may offer some gifts based on users' monthly or yearly transactions as an impulse.

Some incentives may be provided to customers on foreign remittance as physical banking.

Acronyms: There are some acronyms have been used in this paper those are given below;

ABBD - Association of Bankers, Bangladesh

AMPS - Advanced Mobile Phone Service

Apps - Applications

ATM - Automated Teller Machine

CDMA - Code-Division Multiple Access

DPS - Debit Processing Service or Dividends per Share

EU - European Commission

MFS - Mobile Financial Services

NCC - National Credit and Commerce

SMS - Short Message Service

USAID - United States Agency for International

Development

USSD - Unstructured Supplementary Service Data

\section{Conclusion}

As a developing country, Bangladesh can be considered as a glorious example of the successful implementation of mobile banking and it is a key driver for the transaction revolution. The traditional bank included only certain sections of the people where mobile banking included all sections and subsections of the people that is a revolution for us. 'Nagod' a service has changed the environment and activities of the post office of Bangladesh that is also under mobile financial services. Many people have engaged their selves either with business or service for the blessings of this mobile banking over the country that has kept a significant role in our economy. The villagers can get foreign remittance easily using m-banking now and it's growing with time. Considering the rural areas of the country the mobile banking facilities such as transaction limitations, agent selection should be increased with time. Based on time and balanced amount operators may offer a return as profit percentage to its customers monthly or yearly that will attract potential users. Mobile banking maybe a powerful way to do cashless transactions to the billion of people worldwide who have a cell phone but no bank account.

\section{References}

[1] Akhtaruzzaman, M., Islam, M. E., Islam, M. S., -Ul-Islam, S. R., Bhuiyan, M. R., Tareq, M., et al. (2017). An Impact Study onMobile Financial Services (MFSs) in Bangladesh. Research, Bangladesh Bank and Dhaka University, Dhaka.

[2] Andrew, W. (2009). Mobile Banking in Developing Countries (a case study onKenya). Kenya: UNIVERSITY OF APPLIED SCIENCES.

[3] Bangladesh Bank. (2019, November). Mobile Financial Services. Retrieved December 07, 2010, from Bangladesh Bank: https://www.bb.org.bd/fnansys/paymentsys/mfsdata.php.

[4] Bangladesh Bank. (2020). Mobile Financial Services. Dhaka: Bangladesh Bank.

[5] BRAC Bank Company. (2019). Tariff. Retrieved 12 08, 2019, from bKash: https://www.bkash.com/support/tarifflimits/tariff.

[6] Dutch-Bangla Bank Limited. (2019, December 19). DutchBangla Bank Rocket. Dhaka, Bangladesh.

[7] Hasan, M. (2019). BB increases mobile banking transaction limit. Dhaka: Dhaka Tribune.

[8] Islam, M. Z. (2016). Mobile banking sees stellar growth. Dhaka: The Daily Star.

[9] Karnouskos, S., \& Vilmos, A. (2004). The European Perspective on Mobile Payments. IEEE Symposium on Trends in Communications (SympoTIC '04) (pp. 24-26). Bratislava, Slovakia: Research Gate.

[10] Khan, B. S. (2015). Regulatory Guidelines for Mobile Financial Services (MFS) in Bangladesh. Dhaka: The Daily Star.

[11] Mahzabin, F. (2019). Mobile Banking in Bangladesh. Dhaka: Business Haunt.

[12] Ondiege, P. (2010). Mobile Banking in Africa: Taking the Bankto the People. Abidjan: African Development Bank. 
[13] Pathak, A., \& Mishra, S. (2019). Consumer Behavior and Attitude towards Mobile Banking: An Empirical Analysis. International Journal of Innovative Technology and Exploring Engineering (IJITEE), 494-499.
[14] Star Business Report. (2018). Daily transaction via mobile banking Tk 994cr: Muhith. Dhaka: The Daily Star.

[15] Tribune Editorial. (2019). Mobile banking is the way forward. Dhaka: Dhaka Tribune. 